\title{
PHOSPHORUS RECOVERY FROM WASTE AS STRUVITE
}

\author{
Gergana Peeva, Ralitza Koleva, Maya Stancheva, Husein Yemendzhiev, Valentin Nenov
}

\begin{abstract}
The paper gives information on the depletion of phosphorus (P) as an important element for all forms of life and its pollution impact on the environment in case of intensive discharge of phosphorus compounds into water bodies. Two secondary waste sources of Phosphorus are under consideration, namely the domestic wastewater and sludge and animal manure. The characteristics of these two fluids regarding organic matter and nutrient content are summarized. Discussing the techniques for $\mathrm{P}$ extraction mostly attention is given to phosphorus precipitation as ammonium magnesium phosphate (struvite). Examples of effectiveness of $\mathrm{P}$ precipitation as struvite in Municipal Wastewater Treatment Plants (MWWTPs) with chemical and biological $\mathrm{P}$ removal are presented. The examples of struvite production from sewage and manure waste show evidently the great potential of utilization of such a waste as a source of phosphorus. The recovered product is valuable both as it is a slow release fertilizer and with its low content of heavy metals compared to the mineral fertilizers. In respect of the diminishing amount of natural $\mathrm{P}$ rocks, the sewagec wastewater and sludge and the animal manure can be regarded as an important secondary source of Phosphorus.
\end{abstract}

Keywords: phosphorus recovery, wastewater treatment, struvite

\section{INTRODUCTION}

The issue of Phosphorus $(\mathrm{P})$ attracts the world attention in two aspects, namely by its depletion as an important nutrient element and the eutrophication caused by the nutrient pollution [1]. The importance of $\mathrm{P}$ is well recognised, as it is an essential nutrient for all forms of life [2]. Specifically, $\mathrm{P}$ is valuable nutrient in agriculture, a major limiting factor for plant and the entire food production chain. Currently mineral fertilizers are irreplaceable part of modern agriculture. In natural ecosystems, $\mathrm{P}$ is entirely supplied from the weathering of parent materials [3], and the amount of total $\mathrm{P}$ is preserved because it is released back to the soil system through plant residues, animal excreta or when organisms die. In agricultural systems, crop removal represents the primary route by which $\mathrm{P}$ is lost from soils.

\section{P DEPLETION}

Phosphorus $(\mathrm{P})$ is a finite resource obtained mainly from rocks located in few regions of the world. Few countries control over $90 \%$ of the world's phosphorus reserves. Solely Morocco and Western Sahara possess around $73 \%$ of $\mathrm{P}$ rock reserves [4], Fig.1. The only significant source of natural phosphorus in Europe is of Finland. This creates vulnerability to food production systems and increases the need to encourage sustainable phosphorus production practices [4].

\section{Phosphate Rock Reserves Globally}

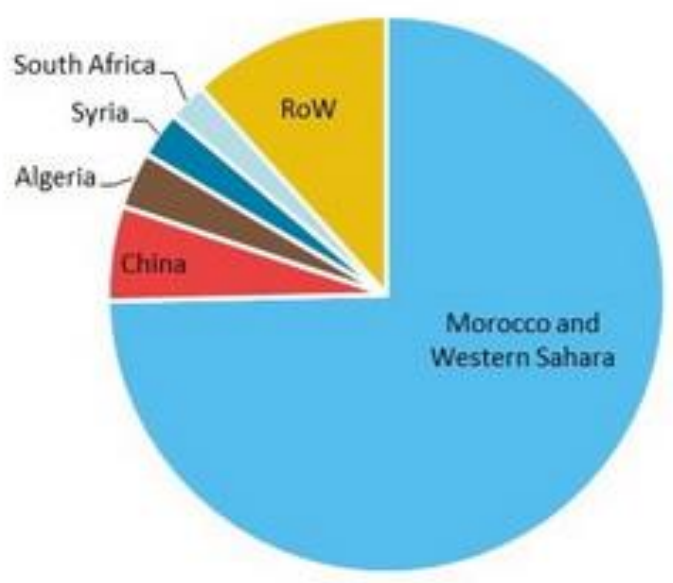

Fig.1. Phosphate Rock: 2020 [5]

Globally, [5] phosphate fertilizer production resulted in $\mathrm{P}$ depletion is sharply increasing reaching in $202036 \mathrm{Mt} \mathrm{P}$ coming from phosphate rock, while in 2009 it was approximately $20 \mathrm{Mt}$ of [6]. It should be mentioned that a considerable of $P$ lost during the whole process of mining-fertiliser 
production. Of all mined and processed phosphate rock in 2009 (32.8 million tons of phosphorus) more than a third is lost during the mining and manufacturing process (11.0 MT), more than half is turned into fertilizers (17.5 MT), and some phosphate rock is used for additives in livestock feed (1.7 MT) and food (0.3 MT). In total 19.5 MT of phosphorus per year goes into the agricultural system Phosphorus rock supply in a baseline development is sufficient for the coming centuries, but the concentration of reserves and the almost complete dependence on imports of the EU and other regions in the world create geopolitical supply risks [7].
Mineral phosphate fertilizers are the primary source of $\mathrm{P}$ input to agricultural lands. Because of the global increase of population and more intensive agricultural activities, the demand for $\mathrm{P}$ is expected to increase in the following years due to continuous population growth and rising global demand for food. Such a prediction was publishes in 2015 [8], Fig. 2. P rocks being a restricted, non-renewable resource is on the EU list of critical raw materials. Worldwide it is recognized that phosphate deposits will last about 50100 years at the current rate of extraction [9]. Even such evaluation is doubt by other authors, there is an increasing concern regarding phosphate rock reserves to become depleted.

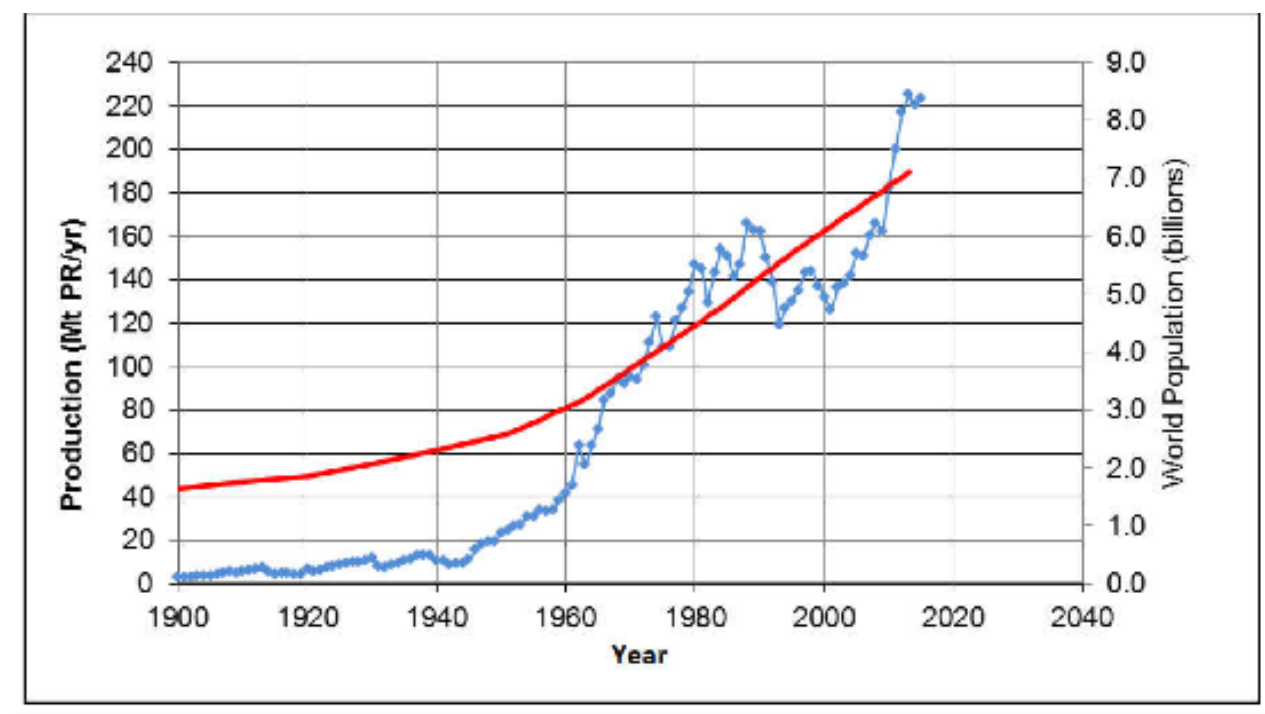

Fig.2. Global production of phosphate rock (blue) coupled with world population (red) in time [8].

\section{P CAUSING EUTROPHICATION}

Eutrophication caused by excessive nutrient releases from agricultural, industrial and urban areas contribute to water quality degradation in many parts of world. It may generate accelerated growth of algae and plants and to follow a wide range of impacts on aquatic ecosystems such as the loss of aquatic biodiversity, create of toxic algal blooms and dead zones. Sensitive areas for eutrophication are all natural water bodies such as rivers, lakes and groundwater as well as coastal and marine waters [10]. Currently, in many countries the problem of eutrophication of closed water bodies has not been resolved. The greatest sources of $\mathrm{P}$ pollution are mainly diffuse-sources, related to agricultural activities and animal production. On the other hand, $P$ point-sources, mainly urban and industrial wastewater are easier to be treated and achieve of $\mathrm{P}$ recovery, since they are usually more concentrated in respect of $P$.

It should be mentioned that besides $\mathrm{P}$ the agriculture is the most important sector for nitrogen releases to aquatic systems and contributes typically $50-80 \%$ to the total load [11]. Modern agricultural practices very often involve an intense use of mineral fertilisers and manure, leading to high nutrient surpluses that are released to aquatic ecosystems. The more intensive agricultural areas are managed the higher is the total area-specific load. Domestic and industrial activities are the most significant source for phosphorus inputs to aquatic systems. While urban sources constitute about 50$90 \%$ of the point source discharges, industrial sources constitute about $17 \%$ [12]. However, due to improved wastewater treatment of municipal and industrial wastewater, the amount of discharged pollutants has decreased significantly since the 1970s. Both, 
treatment technologies and the number of inhabitants connected to sewer and wastewater treatment systems have increased markedly. As these point source discharges have been reduced during the last previous years, agriculture becomes in some regions the most important phosphorus source [12]. In respect of the above, soil erosion and diffuse emissions of phosphorus bound to soil particles becomes the most important pathway. Another important nutrient source is the internal release of nutrients from sediments [13].

The excessive anthropogenic nutrient discharges of the past 100 years have led to an accumulation of nutrients in the sediments of lakes, rivers, estuaries and coastal and marine waters, building up a substantial secondary nutrient source. Along the food value chain, the main "waste" streams, for the EU) are (i) animal manure; (ii) urban wastewater and sewage sludge; and (iii) food processing wastewater [14]. These streams constitute a great loss of valuable nutrients and are causing negative environmental effects, such as water body eutrophication [15].

Besides the important environmental implications based on non-proper wastewater treatment, the great nutrient potential for $\mathrm{P}$ recovery of $\mathrm{P}$ containing waste is recognised. Two specific sources, namely the sewage and manure waste streams are under discussion in this manuscript. An attempt to describe the significance and characteristics of each of these sources will be attempted.

\section{SEWAGE WASTE}

Domestic wastewater and sludge can be regarded as an important secondary source of Phosphorus. Actually, the sludge from Municipal Wastewater Treatment (MWWT) plants is the fluid containing reasonable level of $\mathrm{P}$ allowing economical extraction of this nutrient. There are evidences that sewage has a high potential to recover $\mathrm{PO}_{4}{ }^{3-}$ - because the entire amount of recovered phosphate from municipal wastewater worldwide could theoretically accounts for $15-20 \%$ of the global phosphorus demand [16]. For this reason, the phosphate recovery has high priority in sewage treatment. The national $\mathrm{P}$ budgets in Europe show that municipal wastewater contains a $\mathrm{P}$ load that could theoretically replace 40 to $50 \%$ of the annually applied mineral $\mathrm{P}$ fertilizer in agriculture [17]. Solely in one EU country, Germany, with a potential of 56,700 t Pyr-1 (56\% of all raw material fertilizers), the sewage sludge has the major role among the secondary raw materials. EU estimates that the sludge amount produced annually is over 7 Mt dry solid (DS), while globally, 1.3 Mt P/year is treated in MWWTPs worldwide [18].

Annually, over $56000 \mathrm{t}$ dry sewage sludge is obtained in Bulgaria (a case study in Bulgaria will be discussed herein) according to the national plan for management of sewage sludge from Municipal wastewater treatment plants [19], with a clear tendency with increasing wastewater volumes and advanced wastewater treatment processes, sludge production to be higher [20].

\section{MANURE WASTE}

Manure production another significant waste stream containing $\mathrm{P}$. The amount weight of manure compared to the municipal waste depends strongly of country in interest. Regarding the data on the amount of livestock sludge for the EU countries, it is estimated that sludge production is around 1.4 Mt per year [21], with an approximate distribution of sludge for the EU as follows: $13 \%$ of pig farms; $79 \%$ - cow farms, buffalo farms; about $8 \%$ are from poultry. In the EU, about 1.3-1.8 billion tonnes (wet weight) of manure is produced each year [22]. If $\mathrm{P}$ inputs/outputs in $\mathrm{EU}$ (EU-27) are under evaluation, the available data show that a considerable part of $\mathrm{P}$ exits the system through manure losses [23]. Liquid manure is generated through the animal feeding operations and contains large amounts of nitrogen and phosphorus. It is common to be spread or injected to cropland as an organic fertilizer, directly or after treatment in anaerobic digesters or in natural lagoons. Manure application rates are based on crop nitrogen requirements which results to excessive phosphorus application because phosphorus $(\mathrm{P})$ to nitrogen $(\mathrm{N})$ ratio of animal manure is typically high relative to agronomic requirements [24]. Over application of animal manure to cropland increases the pollutant load of surface and groundwater.

Globally, the comparison of human vs agricultural sources of fecal pollution shows that the agricultural pollution vastly prevails, 86 vs $14 \%$. In addition, the cattle manure with its $57 \%$ is the main stream to the environment [25], Fig. 3.

This graph supported by Oene Oenema [26] and Wim Rulkens [27] shows that in evaluating the by-products and waste sources of $\mathrm{P}$ in Mt per year, Table $1, \mathrm{P}$ in animal manure is almost one order of magnitude higher that in sewage sludge. 


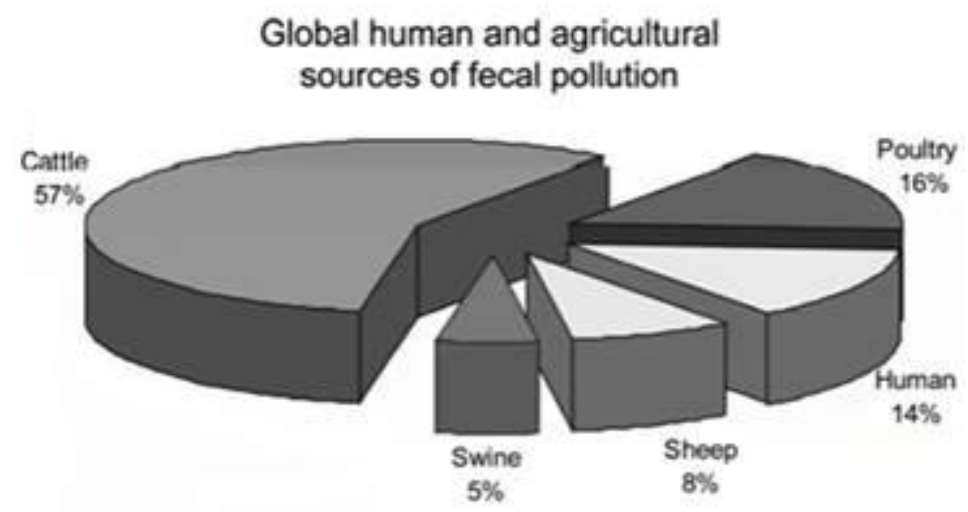

Fig. 3 Comparison of human vs agricultural fecal pollution Phosphorus fertilisers from by-products and wastes [26].

Table 1. Main waste sources of $P$

\begin{tabular}{|c|c|}
\hline Source & $\begin{array}{c}\text { Amount } \\
\text { Mt P per year }\end{array}$ \\
\hline Animal manure & $20-30$ \\
\hline Sewage sludge & $3-5$ \\
\hline
\end{tabular}

The main nutrients bringing by manure are $\mathrm{N}, \mathrm{P}$ and K. A study for the properties of dairy solid matter manure shows nitrogen is mostly represented by ammonia content; total N $2.1 \%$ dry wt., while total $\mathrm{P}$ in average is $0.41 \%$ dry wt., and $0.57 \%$ dry wt. for K. [28]. Regarding the interest to recover nitrogen and phosphorus from the main sources of manure, Table 2 shows soluble species of these nutrients and COD, TSS, $\mathrm{pH}$ as well.

Table 2. Chemical characterization of buffalo, cow and swine manure

\begin{tabular}{|c|c|c|c|c|c|c|c|}
\hline $\begin{array}{c}\text { Type of } \\
\text { waste }\end{array}$ & $\begin{array}{c}\mathrm{PO}_{4}, \\
\mathrm{mg} / \mathrm{L}\end{array}$ & $\begin{array}{c}\mathrm{PO}_{4}-\mathrm{P}, \\
\mathrm{mg} / \mathrm{L}\end{array}$ & $\begin{array}{c}\mathrm{NH}_{4}, \\
\mathrm{mg} / \mathrm{L}\end{array}$ & $\begin{array}{c}\mathrm{NH}_{4}-\mathrm{N}, \\
\mathrm{mg} / \mathrm{L}\end{array}$ & $\mathrm{COD}, \mathrm{g} / \mathrm{L}$ & $\begin{array}{c}\mathrm{TSS}, \\
\mathrm{g} / \mathrm{L}\end{array}$ & $\mathrm{pH}$ \\
\hline Buffalo & 2100 & 687 & 1460 & 1140 & $25-74$ & 18.6 & 8.25 \\
\hline Dairy & 3600 & 1178 & 2160 & 1687 & $15-28$ & 18.5 & 8.4 \\
\hline Swine & 129 & 42.2 & 408 & 318 & $2-2.5$ & 0.25 & 8.15 \\
\hline
\end{tabular}

The high carbon, nitrogen and phosphorus content of manure makes it highly suitable for targeted resource recovery. Resource recovery from manure can be applied in addition to an on-site conventional treatment system at the decentralised level, or in stand-alone centralised manure processing facilities. In recent years, the road to move towards advanced nutrient refinery and recovery systems is becoming more attractive, for several reasons [29]. First, there has been a strong increase in technological developments for nutrient recovery from organic waste streams, such as side stream ammonia stripping in anaerobic digestion. One solution for organic matter removal is anaerobic digestion process. Anaerobic co-digestion of pig manure in full scale biogas plants offers several advantages such as renewable energy (methane) production, reducing pollution, and odours and recycling of nutrients back to the soil [30]. However, often due to intensive pig farming in concentrated areas, not enough agricultural soil is available for utilization of the digested effluents.

\section{TECHNIQUES FOR P EXTRACTION}

Techniques differ by the origin of the used matter (wastewater, sludge, sludge liquor, sludge ash), the applied process (precipitation, wet chemical extraction, and thermal treatment $[18,31]$. One of the most promising technologies is the phosphorus 
precipitation as ammonium magnesium phosphate (struvite) applied in sewage works. Commercial largescale struvite production plants which precipitate struvite from digested sludge liquors are operating in the USA, Canada, and Belgium and recently in China (SCOPE Newsletter, 2012) [32]. However, in spite of the significant progress in struvite recovery technology, a huge room for struvite production optimization still exists. It is reasonable to expect that $\mathrm{P}$ recovery depends on the method of its removal from the wastewater. The most common methods for $\mathrm{P}$ removal are the Chemical Phosphorus Removal (CPR) and the Enhanced Biological P removal (EBPR) [33, 34, 35]. Currently, the biological process for phosphate removal, EBPR, is more attractive despite chemical phosphate removal (e.g. chemical precipitation) used more widely could concentrate phosphate both in liquid (e.g. anaerobic digester supernatant) and solid phases (e.g. sewage sludge/ash. In fact, the phosphorus concentration in sewage is low $(<10 \mathrm{mg} / \mathrm{L})$ while phosphate recovery and reuse are more feasible with rich phosphate in a wastewater stream [36]. To overcome this difficulty, EBPR system shows its high potential to recover phosphate from sewage. For instance, EBPR can be applied to different sewage sources containing $20-100 \mathrm{mg} / \mathrm{L}$ of phosphorus with over $90 \%$ of phosphorus removed. In recent years, a new WWTP paradigm based on the so-called water resource recovery facility (WRRF) concept has emerged for waste-to-resource recovery within the scientific community. Within this paradigm, sewage is no longer considered as a waste but as a source of raw valuable resources, resulting in environmental and economic benefits [37]. Consequently, maximising resource recovery has become a key issue in the sewage treatment field In WWTPs with P removal chemically or biologically, approximately between 75 and $90 \%$ of the phosphorus entering the municipal WWTP is transferred into the sewage sludge [38, 39]. In WWTPs with Enhanced Biological Phosphorus Removal, phosphates are removed from wastewater and accumulated inside the polyphosphate accumulating bacteria (PAO) as internal granules of polyphosphate (Poly- P). During the anaerobic digestion of the sludge, Poly-P is released to the liquid phase. Therefore, the rejected liquors from digested sludge dewatering show high phosphorus, ammonium and magnesium concentrations which make these streams very appropriate for recovering phosphorus as struvite (MgNH4PO4.6H2O) in a crystallisation process.

CPR has the disadvantage of increased sludge volume (by $26 \%$ in activated sludge plants) and reduced $\mathrm{P}$ plant availability compared to EBPR. However, in several cases of municipal wastewater treatment, the less complicated approach then biological approaches, the CPR, is the only way to reach the stringent requirements for residual $P$ because the EBPR can solely rarely ensure $P$ removal efficiency higher than $60 \%$. It is well recognized that the combination of EBPR and sludge digestion offers better opportunity for $\mathrm{P}$ extraction because during the anaerobic stage $\mathrm{P}$ is released in a high extent and makes the struvite precipitation efficient. In CPR based plants the recovery efficiency of $\mathrm{P}$ as struvite is only in the range of 10$50 \%$ of the total influent $\mathrm{P}$ load $[40,41]$ because part of $\mathrm{P}$ is metal bonded in the biomass. In both cases, $\mathrm{CPR}+\mathrm{BPR}$ or EBPR, the struvite precipitation is usually performed on sludge that is digested anaerobically. The high concentration of $\mathrm{P}$ and ammonia in the digested sludge is a pre-requested for the efficient $\mathrm{P}$ precipitation as struvite. The precipitation can be conducted both before and after the dewatering process. The direct precipitated within the sludge has the advantage of improved separation during the dewatering process and lower maintenance because of preventing clogging of pipes and abrasion of centrifuges.

The addition of iron is a convenient way for removing phosphorus from wastewater, but this is often considered to limit phosphorus recovery [42, 43]. The alternative, EBPR is well accepted technology with good perspectives to be vastly implemented, however currently the majority of WWTPs are applying technological schemes with combined CPR/Bio P removal processes (BPR). Based on this reality, the present paper aims to clarify the potential of $\mathrm{P}$ recovery as struvite in applying the combination of CPR + Bio-removal and solely BPR.

Transforming the chemically "locked" phosphates in CPR sludge back into the soluble form is very important for the general yield during phosphorus recovery as struvite. From chemical point of view, the mobilization of ferric phosphate is possible by $\mathrm{Fe}^{3+}$ reduction. A newly discovered path for phosphorus recovery from sewage sludge is the mobilization of orthophosphates from iron phosphate $\left(\mathrm{FePO}_{4}\right)$ by microbial fuel cell (MFC) power [44, 45]. An electrical current is achieved in the microbial fuel cell by attaching electrogens (bacteria like Escherichia coli) to an anode which the bacteria use as electron acceptor. With a proton exchange membrane the anode cell is separated from the cathode cell. The electric flow provides reductive conditions next to the cathode. Thus 
dissolution of up to $82 \%$ of the $\mathrm{FePO} 4$ has been achieved.

While techniques to remove $\mathrm{P}$ from centralized WWTP systems have been developed over several decades, the interest to recover and recycle $\mathrm{P}$ in a usable form is quite recent. There are various methods for phosphorus recovery at waste water treatment plants. In comparison to other waste water streams, municipal wastewaters present the greatest potential for $\mathrm{P}$ recovery because of the large quantity of municipal wastewater produced despite containing small concentration of phosphates [46]. Municipal Wastewater Treatment plants (MWWTPs) provide one of the biggest opportunities for $\mathrm{P}$ recovery [47] given the relatively high and constant $\mathrm{P}$ load in sewage. The recovery of $\mathrm{P}$ from wastewaters can provide an array of benefits: (1) meeting the effluent $\mathrm{P}$ limits required by legislation;
(2) reducing eutrophication problems; and (3) providing a potential source of fertiliser of agricultural and economic value. The latter simultaneously reduces the reliance on inorganic (rock-P derived) fertilisers in agriculture.

An example of the effectiveness of $\mathrm{P}$ precipitation as struvite for MWWTPs with 1) CPR + BPR and 2) BPR will be given herein. Under studies are the plants of Burgas (CPR + BPR) and MWWTP of Pomorie (BPR). Both plants are serving towns situated on the South-East Coast of Black Sea (Bulgaria). The main characteristics of the plants are given in Table 3. The plants are conventional activated sludge systems with D/N zones, Fig.4. Such technology configuration allows a partial bio-de-phosphatation to occur. In the case of Burgas MWWTP, $\mathrm{FeCl}_{3}$ is used as a source of ferric iron. $\mathrm{FeCl}_{3}$ is added to a point before the activated sludge reactor.

Table 3. General characteristics of the MWWPs in study

\begin{tabular}{|c|c|c|c|c|}
\hline WWTP & $\mathbf{P E}$ & P-removal option & $\begin{array}{c}\text { Sludge stabilization } \\
\text { option }\end{array}$ & $\begin{array}{c}\text { Dewatering } \\
\text { technique }\end{array}$ \\
\hline Burgas & 200000 & $\mathrm{CPR} / \mathrm{BPR}\left(+\mathrm{FeCl}_{3}\right)$ & Anaerobic open & Centrifuges \\
\hline Pomorie & 40000 & BPR & Anaerobic open & Centrifuges \\
\hline
\end{tabular}

${ }^{*} \mathrm{FeCl}_{3}$ doses are in range of $1.7-2.4 \mathrm{mgFe} / \mathrm{mgP}$

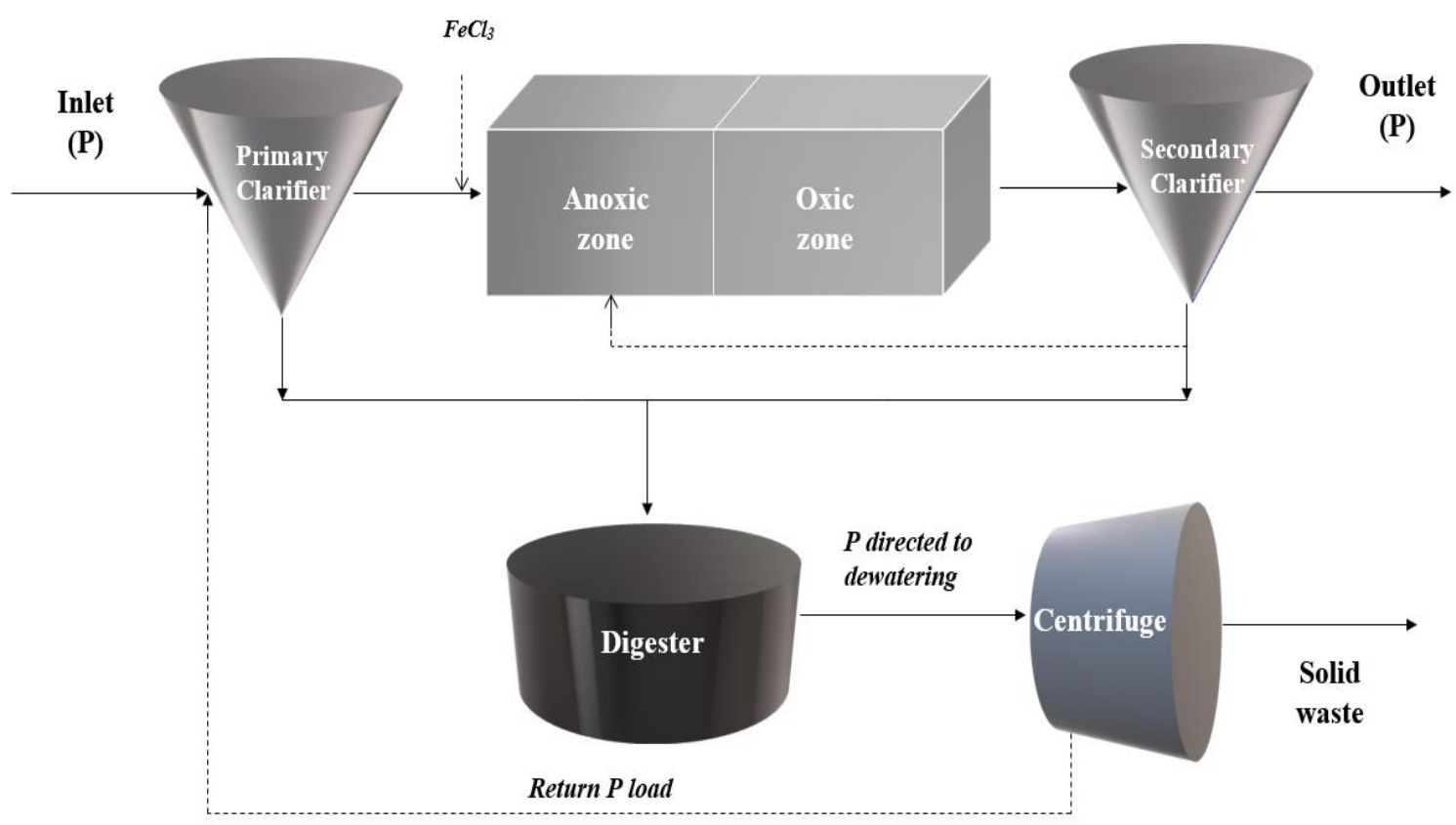

Fig. 4. Principle scheme of the MWWTPs in study

The data obtained shown in Table 4 reveals that a considerable part of $\mathrm{P}$ goes to the return $\mathrm{P}$ stream which is the potential to be recovered, 31 and $41 \%$ towards the inlet load, respectively for Burgas and Pomorie plant. 
Table 4. P balance

\begin{tabular}{|c|c|c|c|c|c|}
\hline MWWTP & $\begin{array}{c}\text { Inlet P } \\
{[\mathrm{kg} \text { P/d] }}\end{array}$ & $\begin{array}{l}\text { Outlet P } \\
{[\mathrm{kg} \text { P/d] }}\end{array}$ & $\begin{array}{c}\text { P directed to } \\
\text { dewatering system } \\
{[\mathrm{kg} \mathrm{P/d}]}\end{array}$ & $\begin{array}{c}\text { Solid waste } \\
\text { [kg P/d] }\end{array}$ & $\begin{array}{c}\text { Returned P } \\
\text { load } \\
{[\mathrm{kg} \mathrm{P} / \mathrm{d}]}\end{array}$ \\
\hline Burgas & 103 & 23 & 120 & 80 & 40 \\
\hline Pomorie & 29 & 15 & 26 & 14 & 12 \\
\hline
\end{tabular}

An attempt to figure out the amount of struvite which can be produced in treatment of dewatering liquor was done. The struvite precipitation

effectiveness was evaluated for each sludge liquor stream based on the average $\mathrm{PO}_{4}{ }^{3-}$ and $\mathrm{NH}_{4}{ }^{+}$ concentrations in the corresponding centrate, Table 5.

Table 5. Phosphate and ammonia levels in the centrate

\begin{tabular}{|c|c|c|}
\hline Plant & $\begin{array}{c}\text { Range of } \mathrm{PO}_{4}^{3-} \\
\mathrm{mg} / \mathrm{l}\end{array}$ & $\begin{array}{c}\text { Range of } \mathrm{NH}_{4}{ }^{+}, \\
\mathrm{mg} / \mathrm{l}\end{array}$ \\
\hline WWTP - Pomorie & $138 \div 250$ & $250 \div 600$ \\
\hline WWTP - Burgas & $86 \div 131$ & $250 \div 500$ \\
\hline
\end{tabular}

The extent of $\mathrm{P}$ removal by struvite precipitation is calculated on the base of preliminary lab experiments. The lab tests show the optimality of molar ratio of $\mathrm{Mg}^{2+} / \mathrm{PO}_{4}{ }^{3-}=2: 1$ and $\mathrm{pH}$ 9. By using brine from Burgas Black sea Bay, magnesium of $59.5 \mathrm{~g} / \mathrm{l}$, calcium $3.5 \mathrm{~g} / \mathrm{l}$. The highest effect of $\mathrm{P}$ removal was reached at these conditions. The high magnesium/calcium ratio is important for effective precipitation of struvite. In excess of calcium, the production of struvite could be suppressed due to the parallel synthesis of the calcium phosphate [48]. Accepting $89 \%$ removal rate of $\mathrm{P}$ as struvite at mole ratio $\mathrm{Mg}^{2+} / \mathrm{PO}_{4}{ }^{3-}=2: 1$ and $\mathrm{pH}$ 9, Fig. 5, and Magnesium Ammonium Phosphate Hexahydrate $\left(\mathrm{NH}_{4} \cdot \mathrm{Mg} \cdot \mathrm{PO}_{4} \cdot 6 \mathrm{H}_{2} \mathrm{O}\right)$ derived from sewage sludge with total $\mathrm{P}$ content of $6.1 \%$ [49] the daily amounts of struvite were calculated, Table 6 .

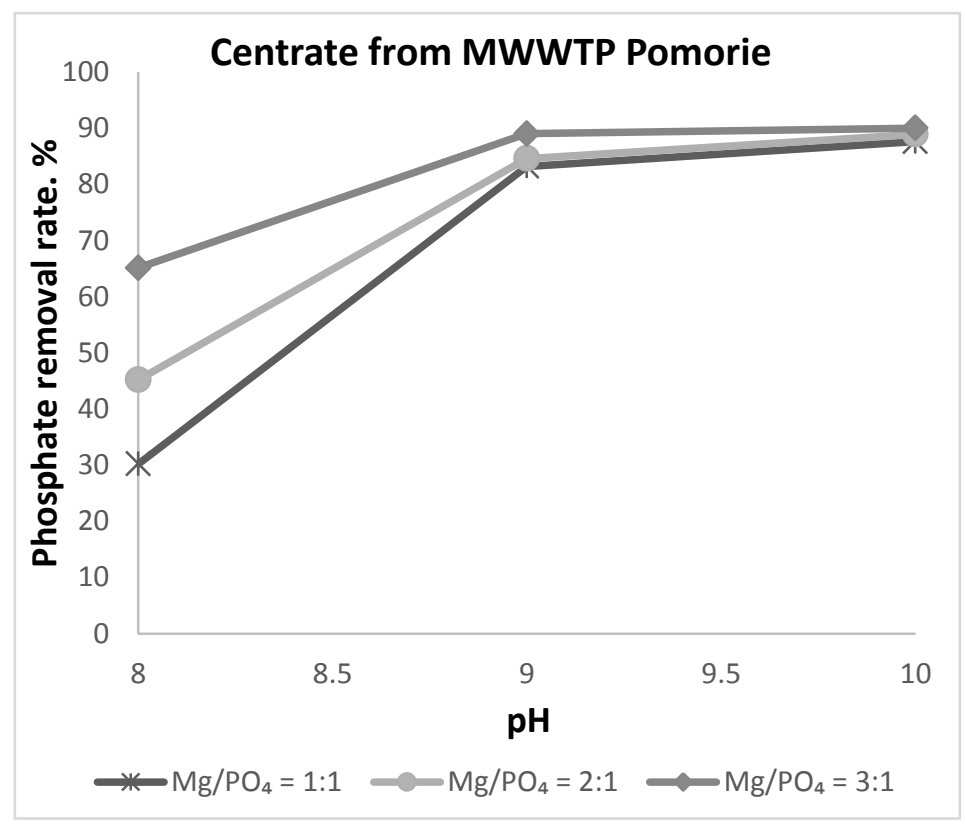

Fig. 4. Phosphate removal rates [\%] at different molar ratios and $\mathrm{pH}$ values 
Table 6. Expected struvite production from sewage waste

\begin{tabular}{|c|c|}
\hline Plant & Daily production, $\mathrm{kg} / \mathrm{d}$ \\
\hline MWWTP - Pomorie & 104 \\
\hline MWWTP - Burgas & 368 \\
\hline
\end{tabular}

*Accepted Average dewatering liquor P concentration for MWWTR Pomorie - $200 \mathrm{mg} / \mathrm{l}$;

**Accepted Average dewatering liquor P concentration for MWWTP Burgas -100 mg/l;

Another example of $\mathrm{P}$ precipitation effectiveness as struvite is given here for animal manure. Fig.5 shows the principal scheme for treatment of most important sources of animal manure waste. Herein, under discussion is the case of $\mathrm{P}$ precipitation from swine waste originated at Krumovo-Gradishte, Bulgaria with daily production of swine manure of $800 \mathrm{~m} 3 / \mathrm{d}$.

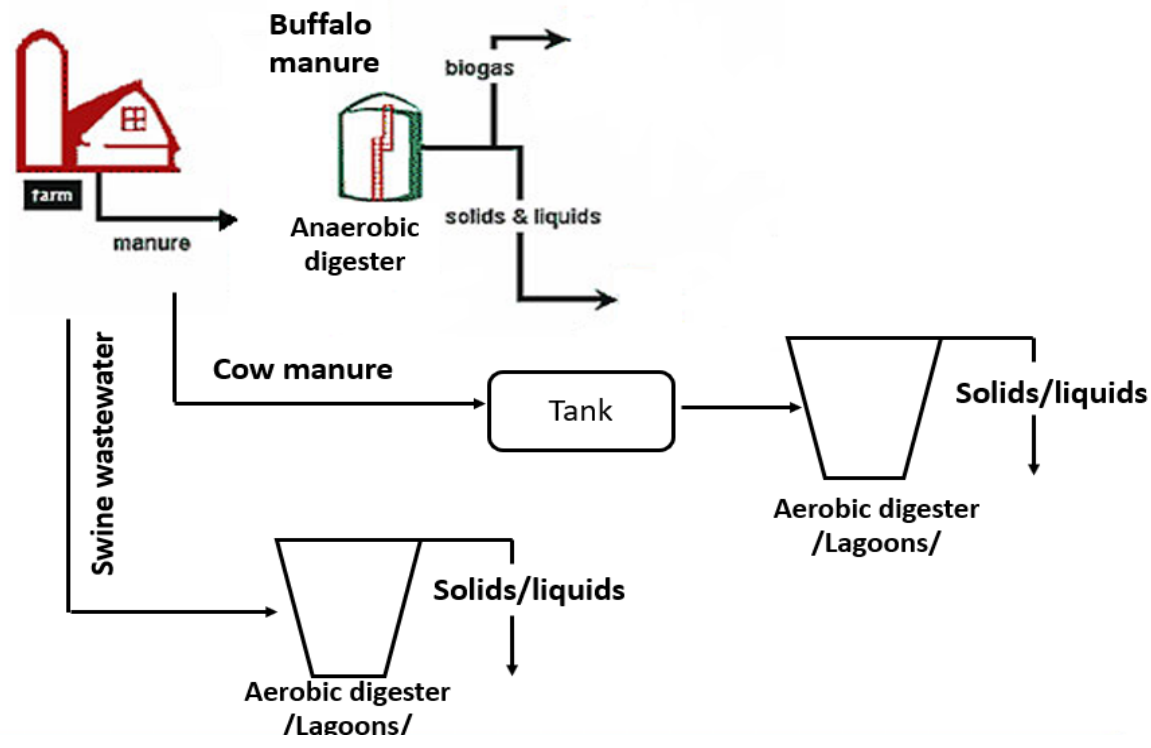

Fig. 5. Principal scheme for treatment of animal manure waste

Similar to the case of sewage waste treatment, the extent of $\mathrm{P}$ removal from swine manure by struvite precipitation is calculated on lab experimental results, i.e. at molar ratio of $\mathrm{Mg}^{2+} / \mathrm{PO}_{4}{ }^{3-}$ $=2: 1$ and $\mathrm{pH} 9$, and applying salt brine $\mathrm{Mg}=59.5 \mathrm{~g} / \mathrm{l}$, $\mathrm{Ca}=3.5 \mathrm{~g} / \mathrm{l}$. The experiment was done by initial centrifugation of the manure at $3000 \mathrm{pm}$ within 15 minutes and filter paper filtration, followed by alkalization by $\mathrm{NaOH}$ and salt brine addition. The chemical characteristics of swine manure after centrifugation and fitter paper filtration is given in Table 7.

Table 7. Chemical characteristics of swine manure after centrifugation and fitter paper filtration

\begin{tabular}{|c|c|c|c|c|c|c|c|c|}
\hline manure & $\begin{array}{c}\mathrm{Mg}, \\
\mathrm{mg} / \mathrm{L}\end{array}$ & $\begin{array}{c}\mathrm{K}, \\
\mathrm{mg} / \mathrm{L}\end{array}$ & $\begin{array}{c}\mathrm{Ca}, \\
\mathrm{mg} / \mathrm{L}\end{array}$ & $\begin{array}{c}\mathrm{PO}_{4}, \\
\mathrm{mg} / \mathrm{L}\end{array}$ & $\begin{array}{c}\mathrm{PO}_{4}-\mathrm{P}, \\
\mathrm{mg} / \mathrm{L}\end{array}$ & $\begin{array}{c}\mathrm{NH}_{4}, \\
\mathrm{mg} / \mathrm{L}\end{array}$ & $\begin{array}{c}\mathrm{NH}_{4}-\mathrm{N}, \\
\mathrm{mg} / \mathrm{L}\end{array}$ & $\mathrm{COD}, \mathrm{g} / \mathrm{L}$ \\
\hline Swine waste & 1.22 & 20.27 & 2.46 & 129 & 42.2 & 408 & 318 & $2-2.5$ \\
\hline
\end{tabular}

Accepting P removal rate of $83 \%$ (lab test results), the daily amounts of Magnesium Ammonium Phosphate Hexahydrate derived from swine manure with $\mathrm{P}$ content of $6 \%$ is calculated for the treatment of the above mentioned swine centrate $(500 \mathrm{~m} 3 / \mathrm{d})$ of $53.5 \mathrm{~kg} / \mathrm{d}$. This result shows that even for treatment of fluid of low P content (swine manure) the struvite production at annual rate is considerable $(19.5 \mathrm{t})$. 


\section{CONCLUSIONS}

The two examples of struvite production from sewage and manure waste show evidently the great potential of utilization of such a waste as a source of phosphorus. The recovered product is valuable both as it is a slow release fertilizer and with its low content of heavy metals compared to the mineral fertilizers. In respect of the diminishing amount of natural $\mathrm{P}$ rocks, the sewagec wastewater and sludge and the animal manure can be regarded as an important secondary source of Phosphorus.

Acknowledgements: This work was supported by Project BG05M20P001-1.002-0019: Clean technologies for sustainable environment - water, waste, energy for circular economy (Clean\&Circle), Centre of Competence; Also supported by the Bulgarian Ministry of Education and Science National Science Fund under project DN17/14.

\section{REFERENCES}

1. Khan F. A., Ansari A. A., Eutrophication: an ecological vision. Bot. Rev., Vol. 71, 2005, 449482.

2. J. J. Elser, Phosphorus: a limiting nutrient for humanity?, Current Opin Biotechnol. Vol. 23, 2012, 833-838.

3. W.H. Schlesinger, Biogeochemistry: An Analysis of Global Change, 1997, 1-588 p.

4. D. Cordell, S. White, Tracking phosphorous security: Indicators of phosphorus vulnerability in the global food system, Food Sec., Vol. 7, 2015, 337-350.

5. Merchant Research and Consulting ltd, Phosphate Rock: 2020 World Market Review and Forecast, April 2020, 1-132.

6. S. M. Jasinski, Mineral Commodity Summaries, US Geological Survey, 2013, 122-123.

7. M. Smits, G. Woltjer, Phosphorus Recycling from Manure: A Case Study on the Circular Economy, Wageningen University and Research, 2018, 61 p.

8. Vaccari, D.A. How do you spot a trend? An examination of recent phosphate rock production. In the special issue on Sustainable Phosphorus. Glob. Environ. Res., Vol. 19, 2015, 3-8.

9. Kelly, T.D., Matos, G.R., Historical statistics for mineral and material commodities in the United States: U.S. Geological Survey Data Series 140, 2014, 3p.

10. ETC/ICM Report 2: European assessment of eutrophication abatement measures across land- based sources, inland, coastal and marine waters, 2016,1-98.

11. ETC/ICM Report 4: Multiple pressures and their combined effects in Europe's seas, 2019, $164 \mathrm{p}$.

12. European Environment Agency, Annual Report 2005, 68 p.

13. Zhongbo Y., Xiaoyan Z., Congrong Yu, Chuanhai W., Peiyi Duan, Lei Wen, Characteristics of nutrient release from sediments under different flow conditions/ Chemical Speciation \& Bioavailability, Vol. 29, 1, 2017, 70-77.

14. Van Dijk K.C, Lesschen J.P., Oenema O., Phosphorus flows and balances of the European Union Member States. Sci. Total Environ., Vol. 542, 2016, 1078-1093.

15. Meng C, Wang Y, Li Y., Zhou J., Li, Y., $\mathrm{Wu}$ J., Deteriorated Water Quality of Agricultural Catchments in South China by Net Anthropogenic Phosphorus Inputs, Sustainability, Vol. 9, 2017, $1480 \mathrm{p}$.

16. Yuan Z., Pratt S., Batstone D.J., Phosphorus recovery from wastewater through microbial processes. Curr. Opin. Biotechnol., Vol. 23, 6, 2012, 878-883.

17. Zoboli, O., Laner, D., Zessner, M., Rechberger, H., 2015. Added values of time series in material flow analysis: the Austrian phosphorus budget from 1990 to 2011, J. Ind. Ecol., Vol. 20 (6), 2015, 1-15.

18. King A. Global water supply \& sewerage, Water \& Environmental International, 1997, 88-95.

19. The National Strategic Plan for the management of sewage sludge from municipal wastewater treatment plants in Bulgaria 2013-2020.

20. Nenov V., Jemendjiev H., Peeva G., Bonev B., Zerrouq F, Struvite recovery options in conventional wastewater treatment plants (WWTPs), J.Mater. Environ. Sci. Vol. 7 (1), 2016, 113-122.

21. Agro Business Park, Manure Processing Activities in Europe, Future trends on manure processing activities in Europe, 2011, 1-34.

22. Meers E., EIP-AGRI Focus Group How to improve the agronomic use of recycled nutrients $(\mathrm{N}$ and $\mathrm{P}$ ) from livestock manure and other organic sources?, Focus group on nutrient recycling, 2016, $1-11$.

23. Van der Eijk, D., B.H. Janssen, O. Oenema, Initial and residual effects of fertilizer phosphorus on soil phosphorus and maize yields on phosphorus fixing soils. A case study in south-west Kenya, Agriculture, Ecosyst. \& Environ., Vol. 116, 2006, 104-120. 
24. Vitti D., E. Kebreab, Phosphorus and calcium utilization and requirements in farm animals, ABI, Animal nutrition, 2010, 178 p.

25. Dufour A., Bartram J., Bos R., Gannon V., World Health Organization (WHO), Animal Waste, 2012, 1-489.

26. O. Oenema, W. Chardon, P. Ehlert, K. van Dijk, O. Schoumans, W. Rulkens, Phosphorus fertilizers from by-products and wastes, The International Fertiliser Society at a Meeting in Cambridge, UK, 2015, 1-56.

27. W.J. Schipper, A. Klapwijk, B. Potjer, W.H. Rulkens, B.G. Temmink, F.D.G. Kiestra, A.C.M. Lijmbach, Phosphate Recycling in the Phosphorus Industry, Phosphorus Res. Bull., Vol. 15, 2004, 47-51.

28. Pettygrove, G.S., I. Bay, Crop nutrient harvest removal. University of California Cooperative Extension, Manure Technical Bulletin Series, 2009, 1-10.

29. Verstraete, W., Clauwaert, P., and Vlaeminck, S.E, Used water and nutrients: recovery perspectives in a 'panta rhei' context. Bioresour Technol., Vol. 215, 2016, 199- 208.

30. W. Verstraete and P. Vandevivere, New and broader applications of anaerobic digestion, Crit Rev Env Sci Tec., Vol. 29, 2, 1999, 151-173.

31. Sartorius C., Horn, J. Von, Tettenborn F., Phosphorus Recovery from Wastewater - State-ofthe-Art and Future Potential. Karlsruhe: Fraunhofer Institute for Systems and Innovation Research., 2011, 1-19.

32. SCOPE Newsletter - $\mathrm{n}^{\circ} 89$ - November 2012, $5 \mathrm{p}$.

33. Bratby, J., Coagulation and Flocculation in Water and Wastewater (2). London: IWA Publishing, 2006, 1-450.

34. Yeoman S, Stephenson T, Lester J.N, Perry R, The removal of phosphorus during wastewater treatment: A review, Environmental Pollution Volume 49, Issue 3, 1988, 183-233.

35. Tanyi A.O., Comparison of chemical and biological phosphorus removal in wastewater - a modelling approach: Master's thesis, Sweden, Water and Environmental Engineering Department of Chemical Engineering Lund University, 2006, 72-78.

36. Geerts, S., Marchi, A., Weemaes, M., Fullscale phosphorus recovery from digested wastewater sludge in Belgium-part II: economic opportunities and risks. Water Sci. Technol., Vol. 71, 4, 2015, 495-502.
37. Puyol D., Batstone D., Editorial: Resource Recovery from Wastewater by Biological Technologies, Front. Microbio., 2017, 1-47.

38. Tarayre, C., Nguyen, H.-T., Brognaux, A., Delepierre, A., De Clercq, L., Charlier, R., Michels, E., Characterisation of phosphate accumulating organisms and techniques for polyphosphate detection : a review, Vol. 16, 6, 1-14.

39. À. Casanova-Martí, J. Serrano, M.T. Blay, X. Terra, A. Ardévol, M. Pinen, Acute selective bioactivity of grape seed proanthocyanidins on enteroendocrine secretions in the gastrointestinal tract, Food Nutr Res., Vol. 61, 1, 2017, Article 1321347

40. Cornel P., Schaum C., Phosphorus recovery from wastewater: needs, technologies and costs. Water Sci Technol., 59, 6, 2009, 10691076.

41. Desmidt E., Ghyselbrecht K., Zhang Y., Pinoy L., Van der Bruggen, Bart, Verstraete, W., Rabaey, K., Meesschaert, B. Global Phosphorus Scarcity and Full-Scale P-Recovery Techniques: A Review. Critical Reviews in Environ. Sci. Technol., 2015, 45, 4, 336-384.

42. Wilfert P, Kumar PS, Korving L, Witkamp GJ, van Loosdrecht MC, The Relevance of Phosphorus and Iron Chemistry to the Recovery of Phosphorus from Wastewater: A Review, Environ Sci Technol. Vol. 49, 16, 2015, 9400-14.

43. Fischer F, Bastian C, Happe M, Mabillard E, Schmidt N., Microbial fuel cell enables phosphate recovery from digested sewage sludge as struvite, Bioresour Technol.,Vol.102(10), 2011, 5824-30.

44. Roland D. Cusick, Bruce E. Logan, Phosphate recovery as struvite within a single chamber microbial electrolysis cell, Bioresource Technology, Vol. 107, 2012, 110-115

45. Budesinsky B. W., A simultaneous EDTAmetric determination of calcium and magnesium with antipyrylazo III and thymolphthalexon. Microchemical Journal, 20, 1, 1975, 17-21.

46. A. Bouzas, N. Martí , S. Grau, R. Barat, D. Mangin, L. Pastor, Implementation of a global Precovery system in urban wastewater treatment plants, J. Clean. Prod., Vol. 227, 2019, 130- 140.

47. Schoumans, O.F., Bouraoui, F., Kabbe, C., Oenema, O., and van Dijk, C.K., Phosphorus management in Europe in a changing world. Ambio 44, 2015, 180- 192.

48. Crutchik D. and Garrido J. M., Struvite crystallization versus amorphous magnesium and calcium phosphate precipitation during the treatment 
of a saline industrial wastewater, Water Science \& Technology, Vol. 64, 2, 2011, 2460-2467.

49. J. Kern, B. Heinzmann, B. Markus, A.C. Kaufmann, N. Soethe and C. Engels. Recycling and Assessment of Struvite Phosphorus from Sewage Sludge. Agricultural Engineering International: the CIGR Ejournal, Vol. 10, 2008, $1-13$.

\section{Assist. Prof. Dr. Gergana Peeva}

\section{Dr. Ralitza Koleva}

\section{Eng. Maya Stancheva}

\section{Assos. Prof. Dr. Husein Yemendzhiev}

\section{Prof. Dr. Valentin Nenov}

Burgas Assen Zlatarov University,

Department of Chemical Technologies,

1, Yakim Yakimov str.,

Burgas, Bulgaria

E-mails: peeva.gergana@abv.bg koleva.ralica@gmail.com maya.atanasova@abv.bg h_bio@yahoo.com vnenov@btu.bg 